\title{
Kamienne obiekty Drogi Krzyżowej w Kalwarii Zebrzydowskiej
}

\section{The stone structures of the Way of the Cross in Kalwaria Zebrzydowska}

\author{
Przemysław Nowak, Marek Rembiś \\ Katedra Geologii Złożowej i Górniczej, Wydziat Geologii, Geofizyki i Ochrony Środowiska, \\ Akademia Górniczo-Hutnicza, Al.Mickiewicza 30, 30-059 Kraków \\ e-mail:pnowak@geol.agh.edu.pl;mrembis@geol.agh.edu.pl
}
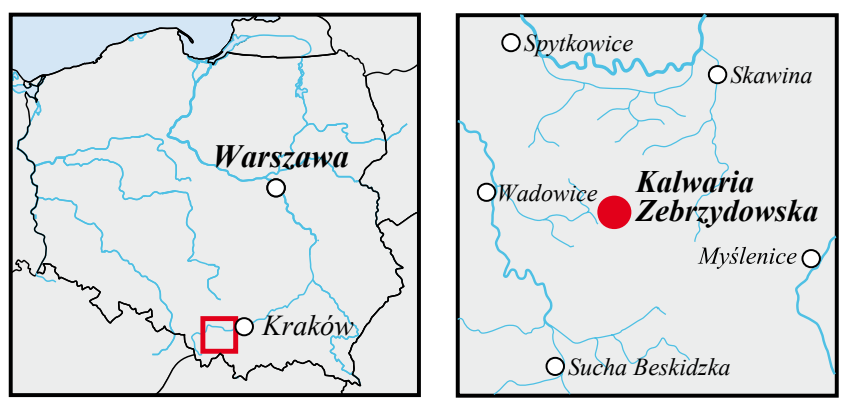

Treść: $W$ artykule przedstawiono atrakcje geoturystyczne usytuowane w poblizu Drogi Krzyżowej w Kalwarii Zebrzydowskiej. Ten sakralny kompleks składa się z 44 różnego rodzaju kościołów i kaplic rozciagniętych wzdluż trasy o dlugości równej prawie $8 \mathrm{~km}$. $W$ kaplicach można podziwiać wyjatkowe przykłady zastosowania piaskowców dolnolgockich jako materiatu budowlanego, a także zapoznać się z dawnq sztuka kamieniarska, zgodnie $z$ którq zostat obrobiony materiat kamienny.

Slowa kluczowe: Kalwaria Zebrzydowska, kamienie budowlane, piaskowce lgockie

Abstract: The paper presents selected geotouristic attractions situated near the Way of the Cross in Kalwaria Zebrzydowska the village. This sacral complex, cosisted of th 44 small chapels of various types, spreads along a route almost $8 \mathrm{~km}$ long. The chapels are an exceptional example of applying th Lower Lgota sandstones to constructing purposes. They also give us chance to get acquainted with the old art of masonry, according to which the stone material was utilized.

Key words: Kalwaria Zebrzydoska, building stones, Lgota sandstones

\section{Wstęp}

Niemal każdy z nas przynajmniej raz w życiu słyszał o Kalwarii Zebrzydowskiej położonej około $36 \mathrm{~km}$ od Krakowa. Nazwa tego stosunkowo niedużego miasta wielokrotnie ukazywała się w mediach, czy to przy okazji dorocznej uroczystej Drogi Krzyżowej, czy też wizyt papieży: Jana Pawła II i jego następcy Benedykta XVI. Co jednak sprawiło, że wśród wielu miejsc kultu religijnego w Polsce, akurat to stało się tak ważne? Odpowiedź na to pytanie związana jest przede wszystkim z malowniczo położonym, unikatowym w skali europejskiej, kompleksem sakralnym, na który składają się klasztor oraz 44 różnego rodzaju kościoły i kaplice, rozciągnięte wzdłuż trasy o długości równej prawie $8 \mathrm{~km}$ (Fig.1). Bogactwo form architektonicznych (głównie barokowych) w połączeniu z niezwykle urokliwą scenerią terenu, na którym są zlokalizowane, a także z ponad 400-letnią historią

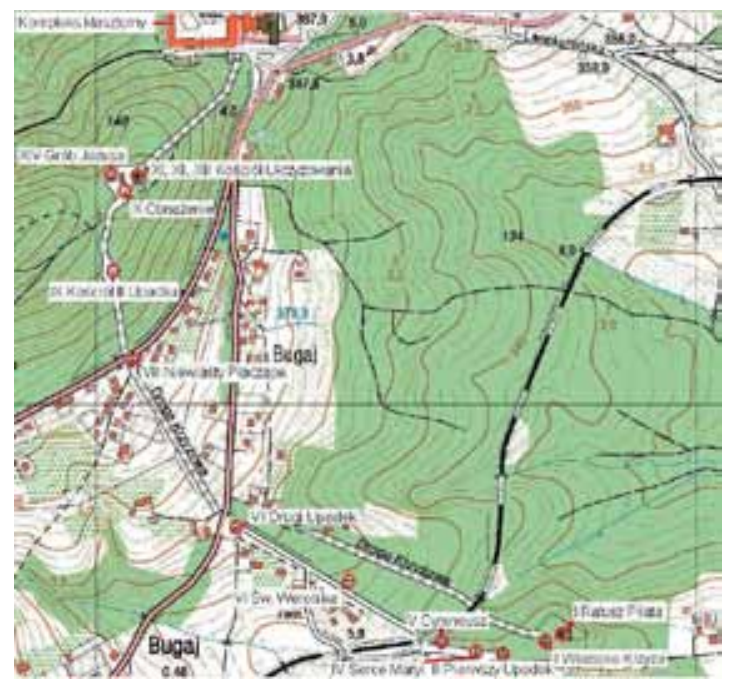

Fig. 1. Rozmieszczenie kaplic Drogi Krzyżowej na tle mapy topograficznej Kalwarii Zebrzydowskiej (podkład topograficzny www.wrotamalopolski.pl) - Location of chapels of the Way of the Cross on the topographical background (topographical undercoat www.wrotamaloposki.pl)

kultu religijnego sprawiły, iż zabytki zaliczane do kalwaryjskich ścieżek modlitewnych, zostały wpisane 1 grudnia 1999 r. na Listę Światowego Dziedzictwa UNESCO, jako jedyne tego typu na świecie. Można także podziwiać na przykładzie kaplic wyjątkowe w skali kraju zastosowanie piaskowców dolnolgockich w budownictwie, a także zapoznać się z dawną sztuką kamieniarską, zgodnie z którą został obrobiony materiał kamienny.

\section{Fundator Mikołaj Zebrzydowski, czyli historia budowy...}

Historia fundacji, budowy klasztoru i pierwszych kaplic w Kalwarii Zebrzydowskiej związana jest nierozerwalnie z dziejami rodu Zebrzydowskich herbu Radwan, o których pierwsze wzmianki na ziemiach Małopolski pochodząjuż z XII w. Większą sławę zyskali oni jednak dopiero w XVI w. Najbardziej znanym z Zebrzydowskich był, bez wątpienia, Mikołaj - pomysłodawca budowy klasztoru i kaplic. W 1583 r. ożenił się z Dorotą z Dobromiłów - cioteczną siostrą kanclerza i hetmana wielkiego koronnego Jana Zamojskiego, prywatnie serdecznego przyjaciela Mikołaja. Właśnie ta znajomość oraz wstawiennictwo Jana u króla Stefana Batorego umożliwiły Zebrzydowskiemu objęcie w 1585 r. stanowiska starosty generalnego krakowskiego, a w 1588 r. zaowocowało otrzymaniem we władanie starostwa lanckorońskiego (Wyczawski, 2006). 


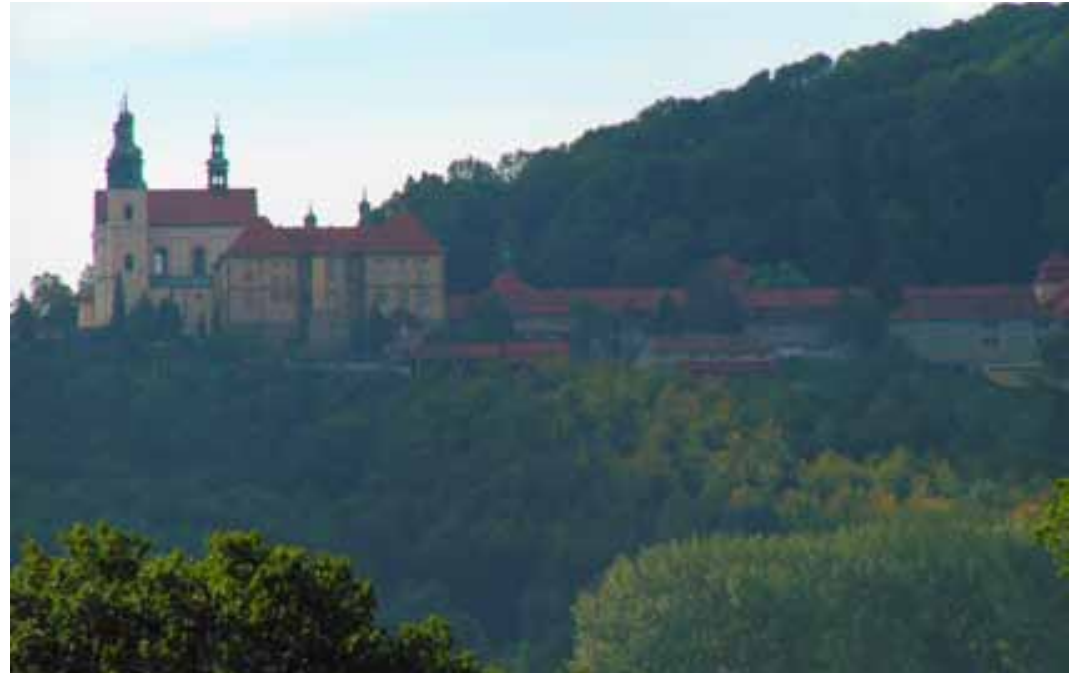

Fig. 2. Widok na klasztor w Kalwarii Zebrzydowskiej od strony wschodniej, fot. G. Krupa - A view at the monastery complex in Kalwaria Zebrzydowska from the east, phot. G. Krupa

Rezydujący najczęściej na zamku lanckorońskim Mikołaj i Dorota Zebrzydowscy niejednokrotnie mieli możliwość podziwiania widoku słońca zachodzącego za zboczem góry Żarek. Być może jest ziarno prawdy w przekazie, mówiącym o tym, że Mikołaj patrząc wieczorną porą w kierunku tego wzgórza doznał widzenia, co skłoniło go do ufundowania na nim pustelni i dużego krzyża (inna opowieść podaje, że widzenia doznała żona Dorota, po czym namówiła męża do upamiętnienia tego wydarzenia). Skromną początkowo inwestycję Mikołaj zrealizował w 1596 r. Tego samego roku na pielgrzymkę do Ziemi Świętej wyruszył Hieronim Strzała, dawny dworzanin Zebrzydowskiego. Mikołaj, zaopatrzywszy go w odpowiednią sumę pieniędzy i list polecający do sułtana, zobligował go do przywiezienia planów jerozolimskiej kaplicy Ukrzyżowania. W 1599 r. Strzała powrócił z pielgrzymki, przywożąc gipsowy odlew nie tylko kaplicy Ukrzyżowania, ale i Grobu Chrystusa. Z rozpoczęciem budowy Zebrzydowski zaczekał do 1600 r. Kamień węgielny pod zaplanowaną kaplicę św. Krzyża położono 4 X 1600 r., a budowę ukończono rok później. Wzniesiona kaplica, wykonana ściśle według przywiezionego przez Strzałę odlewu gipsowego, była mniej więcej o połowę mniejsza od obecnego kościoła Ukrzyżowania. Data ukończenia budowy zbiegła się z nominacją Zebrzydowskiego na wojewodę krakowskiego (funkcję tę sprawował aż do śmierci). Nim Mikołaj zdecydował się na budowę kolejnych kaplic, postanowił sprowadzić do Kalwarii powstającej na zboczach Żarka zakon bernardynów, który miałby piecze nad wznoszonymi kaplicami. W zamian wojewoda zobowiązał się wybudować klasztor dla zakonników. Kamień węgielny pod budowę położono 2 VIII 1603 r. Projektantem był początkowo włoski jezuita br. Jan Bernardoni, jednak plan zawierał pewne błędy, dlatego pieczę nad dokończeniem projektu, a następnie nadzorem budowy, przejął belgijski architekt, Paweł Baduarth. Zebrzydowski był tak zadowolony z usług architekta z Antwerpii, że zlecił mu także zaprojektowanie kaplic Drogi Krzyżowej. Przygotowania do tego przedsięwzięcia rozpoczęły się już w trakcie budowy klasz- toru w 1604 r. Realizując nakreślony plan, w 1605r. przystąpiono do budowy Ratusza Piłata i kaplicy Grobu Chrystusa. Jednak radość Zebrzydowskiego z rozpoczętej kolejnej już inwestycji zmąciła śmierć Jana Zamojskiego. Mikołaj został uwikłany w nieudany rokosz szlachty przeciwko królowi, w wyniku którego popadł w niełaskę i odsunął się od życia politycznego. Po tym zajściu upokorzony Zebrzydowski całą swoją uwage skupił niemal wyłącznie na rozpoczętej przez siebie inwestycji. Prace nad budową kościoła i klasztoru wyraźnie przyśpieszyły i jeszcze tego samego roku zostały niemal ukończone. W 1609 r. ukończono budowę Ratusza Piłata, Grobu Chrystusa, Ogrojca, kaplicy Pojmania Chrystusa, Domu Kajfasza, Domu Annasza oraz Pałacu Heroda. Po 1609 r. nastąpiła dwuletnia przerwa w budowie kaplic, spowodowana problemami finansowymi Zebrzydowskiego (zapewnienie posagu 3 córkom i ślub jedynego syna Jana). W 1610 r. zmarła żona Mikołaja, Dorota. Po jej śmierci Zebrzydowski jeszcze intensywniej zaczął praktykować cnoty pokory i ubóstwa (Wyczawski, 2006).

W 1611 r. wznowiono budowę świątyń kalwaryjskich. Zebrzydowski zaczął od kaplicy Grobu Matki Boskiej. W latach 1612-1614 zbudowano Dom Matki Boskiej, a w 1614 r. kaplicę Wniebowstąpienia Pana Jezusa i kaplicę Włożenia Krzyża. W 1615 r. ukończono budowę kaplicy Wieczernika oraz kaplicy Spotkania Chrystusa ze swą Matką. Rok później powstała kaplica Bramy Wschodniej zwana „Drugim Upadkiem Chrystusa". Kolejny rok prac przyniósł efekty w postaci kaplicy św. Rafała, kaplicy Pięciu Braci Polaków oraz Pustelni św. Marii Magdaleny. Po zbudowaniu tych obiektów po raz kolejny Zebrzydowski przerwał prace budowlane, ponieważ musiał zebrać nowe fundusze. Nie zdążył jednak ukończyć wielkiego dzieła, gdyż zmarł nagle 17 V 1620 r. Został pochowany, wbrew swej woli, (chciał spocząć w Kalwarii obok kościoła klasztornego), na Wawelu, w kaplicy Zebrzydowskich, obok zmarłej 10 lat wcześniej żony. Ogółem za sprawą Mikołaja Zebrzydowskiego, prócz budynku klasztornego i kościoła głównego, stanęło w Kalwarii siedemnaście kaplic (Wyczawski, 2006).

Opiekę nad Kalwarią i dalszą jej rozbudową przejął po śmierci Mikołaja jego syn, Jan. Ponieważ, podobnie jak ojciec, był człowiekiem bardzo pobożnym, już 3 lata po śmierci ojca rozpoczął budowę kolejnej kaplicy, Bramy Wschodniej, a rok później kaplicy Obnażenia. Niestety, nie są znane dokładne daty budowy innych kaplic ani chronologia prowadzonych przy nich prac. Jednak między 1620 a 1642 r., za sprawą Jana Zebrzydowskiego, stanęły jeszcze kaplica Pierwszego Upadku, kaplica Szymona Cyrenejczyka, kaplica św. Weroniki i kaplica Znalezienia Krzyża z Pustelnią św. Heleny, prezentujące jednak znacznie uboższy poziom architektoniczny niż te, ufundowane za życia Mikołaja Zebrzydowskiego. Wybudowano też wtedy Święte Schody, nazywane „Gradusami”, prowadzące do Ratusza Piłata oraz kapliczki z serii Dróżek Matki Boskiej, z których, niestety, żadna nie dotrwała do dzisiejszych czasów. Na znacznie wyższym po- 
ziomie został wykonany kościół Grobu Matki Boskiej i powiększenie kościoła Ukrzyżowania. To właśnie z budowy tych dwóch świątyń najbardziej zasłynął Jan Zebrzydowski. Stanowią one prawdziwe perełki architektoniczne.

Reasumując należy stwierdzić, że Jan Zebrzydowski wzniósł więcej obiektów od swego ojca, ale prócz kościoła Grobu Matki Boskiej i kościoła Ukrzyżowania były one mniej wartościowe pod względem architektonicznym. Przyczyna tkwiła w tym, iż Jan zaczynał zbyt wiele inwestycji naraz, co przekraczało jego możliwości materialne (Wyczawski, 2006).

Ostatnim Zebrzydowskim, na którym wygasła linia rodu, był syn Jana, Michał. Wsławił się on jednak jedynie rozbudową klasztoru w Kalwarii i budową kaplicy Cudownej Matki Boskiej. W 1664 r. Michał został starostą generalnym krakowskim, a w 1667 r. na kilka dni przed śmiercią - wojewodą krakowskim. Ponieważ miał tylko dwie córki, cały majątek przeszedł na własność córki Anny, żony Jana Karola Czartoryskiego, zaś ród Zebrzydowskich wygasł.

Po śmierci Anny, jej mąż, Jan Karol Czartoryski, wierny tradycji Zebrzydowskich, przejął opiekę nad Kalwarią, a jego druga żona, Magdalena z Konopackich, zasłużyła na miano fundatorki, dzięki dobudowaniu nawy przy kościele konwenckim. Jednak wraz z jej śmiercią w 1694 r. skończyła się epoka wielkich fundatorów (Wyczawski, 2006).

\section{Co można zobaczyć, czyli wędrówki po szlakach Kalwarii}

Kalwaria Zebrzydowska położona jest w bardzo malowniczym terenie, zlokalizowanym na pograniczu Beskidu Makowskiego i Pogórza Wielickiego. Miasto leży na wysokości 335-400 m n.p.m. u podnóża góry Żarek (527 m n.p.m.) korespondującej od południowego-wschodu z Górą Lanckorońską (550 m n.p.m.), na której znajdują się ruiny zamku z XIII w. Przez Kalwarię Zebrzydowską przebiega bardzo ruchliwa trasa z Bielska-Białej do Krakowa, a także linia kolejowa z Wadowic do Krakowa. Miasto stanowi więc naturalny przystanek dla pielgrzymów podróżujących tzw. Szlakiem Jana Pawła II, który zaczyna się w rodzinnym mieście Karola Wojtyły tj. w Wadowicach, dalej przebiega właśnie przez Kalwarię i kończy swój bieg w Krakowie.

Będąc już w Kalwarii Zebrzydowskiej dotarcie do obiektów sakralnych nie nastręcza trudności, gdyż górujący nad miastem klasztor jest widoczny niemal z każdego miejsca (Fig. 2).

Prowadzi do niego kilka dróg, jednak najłatwiej trafić tam podążając od rynku w kierunku klasztoru łagodnie wijącą się pod górę drogą asfaltową. Już przy samym klasztorze widać, że duża część kompleksu sakralnego znajduje się w scenerii lasu (m.in. kościół Ukrzyżowania, Grób Jezusa czy kościół III Upadku). Warto w tym miejscu wyjaśnić, iż większość obiektów podzielona jest tematycznie na dwie grupy: Dróżki Pana Jezusa i Dróżki Matki Boskiej, biegnące w przeciwnych kierunkach. Ponadto, napotykamy też sporą ilość innych obiektów, jak choćby Pustelnia św. Heleny, pozostających poza cyklem dróżkowym.

Wśród ciekawszych obiektów sakralnych zlokalizowanych w pobliżu klasztoru należy wymienić wspomniany już ko- ściół Ukrzyżowania i Grób Chrystusa, do których wiedzie stroma kamienista ścieżka, stanowiąca jednocześnie początek zielonego szlaku prowadzącego grzbietem góry Żarek do wsi Bugaj. Już po przejściu kilku metrów od klasztoru pod stopami pojawiają się wychodnie piaskowców górnolgockich, zapadających pod kątem $52^{\circ}$. Stanowią one nie lada utrudnienie, zwłaszcza dla osób starszych przemierzających tę ścieżkę, gdyż miejscami wystają kilkadziesiąt cm ponad poziom terenu (Fig. 3).

Mniej więcej w połowie drogi z klasztoru na szczyt góry Żarek znajduje się niewielkie wypłaszczenie, na którym wybudowano 3 obiekty: kościół Ukrzyżowania, Grób Jezusa i kaplicę Namaszczenia. Jest to też jednocześnie doskonały punkt wyjścia w dalszą wędrówkę. A opcji jest kilka. Idąc w kierunku zachodnim, dotrzemy do wsi Bugaj, gdzie znajduje się stanowisko dokumentacyjne jednego z egzotyków karpackich, tj. porwaka granitowego, tkwiącego wśród łupków wierzowskich, tzw. ,granitu z Bugaja”.

Warto od razu dodać, że najprawdopodobniej także ta skała została wykorzystana przy budowie kaplic, czego przykładem moga być schody granitowe w „Gradusach” prowadzące do pierwszej stacji Drogi Krzyżowej - Ratusza Piłata.

Po minięciu najbardziej wysuniętej na zachód kaplicy tj. Samotni Marii Magdaleny, od szlaku w lewą stronę odchodzi odnoga, prowadząca do starego nieczynnego już kamieniołomu o nazwie „Maria Magdalena”, znajdującego się na południowym stoku góry Żarek. Był w nim kiedyś eksploatowany piaskowiec lgocki poziomu dolnego, którego użyto do budowy większości obiektów sakralnych w Kalwarii Zebrzydowskiej. Odsłonięcie to jest jednym z najlepszych i chyba jedynym ukazującym tak dobrze cały profil warstw dolnolgockich. Warstwy te ze względu na soczewowy charakter występowania oraz niewielką miąższość (do $20 \mathrm{~m}$ ) niezwykle rzadko odsłaniają się na powierzchni. Trzeba też dodać, że ze szczytu kamieniołomu roztacza się przepiękny widok na całą południowo-wschodnią stronę Kalwarii i jej okolice (Fig. 4).

Na przeciwległym stoku, a więc na północno-zachodnim zboczu góry Żarek, znajduje się dość duże odsłonięcie warstw lgockich poziomu górnego. Jednak poza tymi dwoma efektownymi odsłonięciami, bądź co bądź obszarami naruszonymi już przez człowieka, mamy także możliwość podziwiania innych, tym razem już czysto przyrodniczych osobliwości. Stoki góry Żarek pokryte są lasami chronionymi, a w ma-

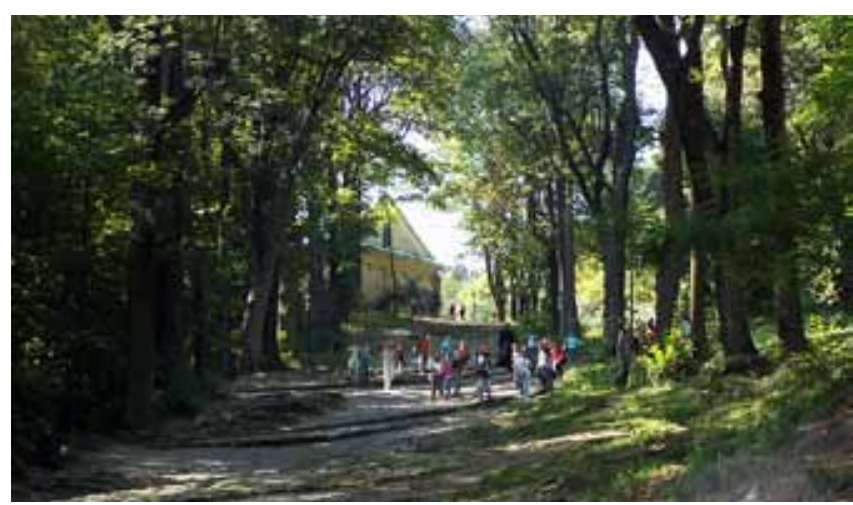

Fig. 3. Droga prowadząca od klasztoru do kościoła Ukrzyżowania, fot. P. Nowak - A path from the monastery to the Church o Crucifixion, phot. P. Nowak 


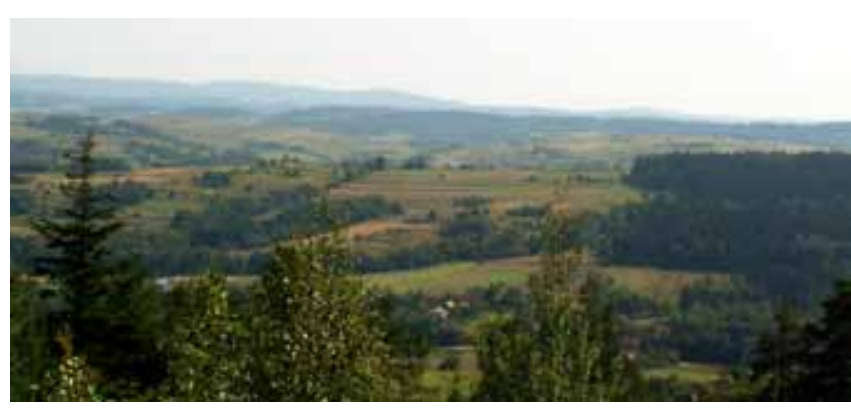

Fig. 4. Panorama wsi Bugaj ze szczytu góry Żarek tuż nad kamieniołomem „Maria Magdalena”, fot. P. Nowak • A view of Bugaj village from the top of the Żarek hill, directly up of the "Maria Magdalena" quarry, phot. P. Nowak

lowniczej scenerii gęstego lasu mieszanego oraz na jego obrzeżach możemy natrafić na rzadkie gatunki ściśle chronionych roślin, takich jak: barwinek pospolity, bluszcz pospolity, dziewięćsił bezłodygowy, gółka ostrogowa, obuwik pospolity, skrzyp olbrzymi i wawrzynek wilczełyko (Kowalik, 2004). Nic więc dziwnego, że rejon ten należy do korytarza ekologicznego o znaczeniu krajowym, który jest wpisany do mapy krajowego systemu ekologicznego ECONET.

Wracając jednak do wspomnianego wcześniej wypłaszczenia, gdzie znajduje się m.in. kościół Ukrzyżowania, należy przedstawić także znacznie bardziej oczywisty kierunek wędrówki, bowiem zamiast wspinać się szlakiem na szczyt Żarka, można po prostu zejść w dół (kierunek południowo-zachodni) w stronę pozostałych kaplic Drogi Krzyżowej. Rozwiązanie takie jest wprawdzie sprzeczne z chronologią obiektów tworzących kalwaryjskie dróżki, zaczyna się zwiedzanie od końca, jednak jest nieco wygodniejsze, gdyż chcąc dotrzeć od klasztoru do pierwszej stacji - Ratusza Piłata i tak jesteśmy zmuszeni do przejścia ponad połowy Drogi Krzyżowej w odwrotnej kolejności. Dlatego też zwiedzanie najlepiej zacząć od kończącej Drogę Krzyżową kaplicy Grobu Chrystusa (Fig. 5).

Jest ona zwrócona frontem do wschodu i wzniesiona całkowicie z kamienia ciosowego. Projekt kaplicy był wzorowany na oryginalnej kaplicy Grobu Chrystusa, znajdującej się

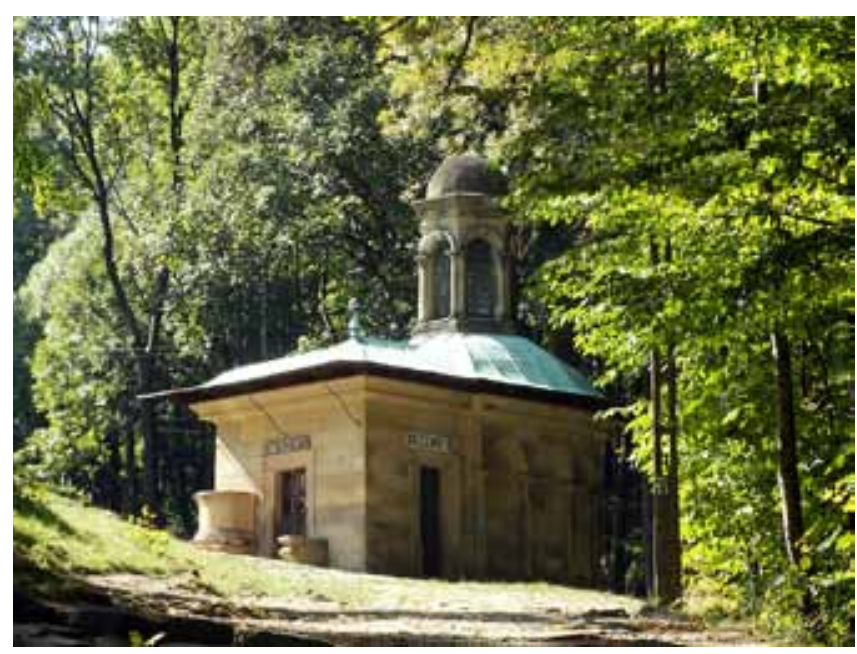

Fig. 5. Kaplica Grobu Chrystusa - widok od strony klasztoru, fot. P. Nowak - The Chapel of Christ's Sepulchre - a view from the monastery side, phot. P. Nowak w Ziemi Świętej. Jej rzut poziomy ma na zewnątrz kształt prostokąta, zamkniętego od zachodu pięcioma bokami dwunastoboku, wewnątrz zaś rozdziela się na dwie części: wschodnią, prostokątną oraz zachodnią, kwadratową. Na dachu znajduje się efektowna latarnia wsparta na kolumnach jońskich. Niestety kaplica jest silnie zniszczona, a piaskowiec na elewacji jest zabrudzony z licznymi nawarstwieniami pyłowymi. Nieco powyżej Grobu Chrystusa znajduje się kościół Ukrzyżowania (Fig. 6).

Jest on zwrócony fasadą do zachodu, wzniesiony częściowo z kamienia ciosowego, częściowo z kamienia łamanego i z cegły. Szczegóły architektoniczne wykonano w kamieniu ciosowym. Plan kościoła ma kształt prostokąta. Dwa filary i dwa półfilary połączone są ze sobą arkadami i dzielą go na dwie połowy. Do podziałów architektonicznych wnętrza użyto pilastrów i półpilastrów toskańskich (J. Szablowski, 1933). Budynek z pewnością sprawiałby jeszcze lepsze wrażenie gdyby został odnowiony, gdyż jest on silnie zabrudzony, a użyte do budowy bloki piaskowca wykazują obecność licznych ubytków.

Nieco poniżej kościoła Ukrzyżowania (w kierunku południowym) znajduje się niewielka i znacznie mniej efektowna kaplica Obnażenia o kształcie prostokątnego, sklepionego beczkowo korytarza. Kilkadziesiąt metrów dalej, tuż przed bardzo stromym zejściem w kierunku kolejnych kaplic, znajduje się bardzo duży budynek - kościół III Upadku, stanowiący IX stację Drogi Krzyżowej (Fig.7). Posiada on prostokątny rzut, z półkolistą apsydą i kwadratową zakrystią od frontu. Elewacja i elementy cokołowe wykonane są z kamienia łamanego i z cegły, najprawdopodobniej jest to, podobnie jak w wielu innych kaplicach, mur zasypowy, a więc konstrukcja składająca się z gruzu kamiennego obłożonego z jednej i z drugiej strony starannie ociosanymi płytami okładzinowymi. Detale architektoniczne są wykonane z piaskowca.

Schodząc dalej, po wykonanych z piaskowca dolnolgockiego schodach, dociera się do drogi asfaltowej prowadzącej do wsi Bugaj. Przy jezdni znajduje się kaplica Niewiast Płaczących, nieotynkowana i wykonana głównie z cegły.

Do kolejnej kaplicy przechodzi się dość szeroką, położoną prostopadle do jezdni aleją, wzdłuż której można podziwiać 200-250 letnie pomniki przyrody: lipy i dęby. Idąc dalej aleję tę przecina kolejna droga asfaltowa, obok której znajduje się pokaźnych rozmiarów stacja VII Drogi Krzyżowej zwana Bramą Zachodnią (lub „II Upadkiem”) (Fig. 8).

Do jej wnętrza prowadzą półokrągłe wejścia, na przestrzał, od wschodu i zachodu (odrzwia prostokątne). Na zewnątrz ściany podzielone są na dwa piętra okazałym gzymsem, podtrzymywanym po stronie wschodniej przez dwie półkolumny i trzy konsole. Piętro górne jest o połowę niższe od dolnego i podzielone przez cztery półkolumny, stojące na gzymsie. W środku piętra górnego mieści się herb Ziemi Świętej (Szablowski, 1933).

Podążając dalej deptakiem mija się po lewej stronie Pałac Heroda, niezaliczany do stacji Drogi Krzyżowej, natomiast włączony do tzw. Dróżek Pana Jezusa. Z kolei tuż przed kładką znajdującą się ponad torami kolejowymi usytuowana jest najmniejsza z kaplic tj. św. Weronika, którą stanowi jedynie figurka zadaszona baldachimem wspartym na czterech kolumnach jońskich. 


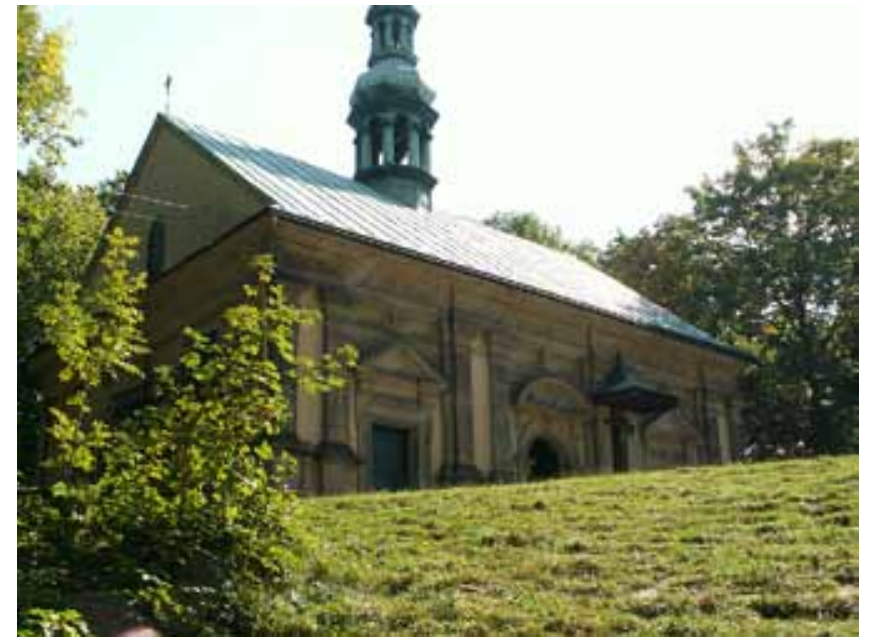

Fig. 6. Kościół Ukrzyżowania - widok od strony kaplicy Grobu Chrystusa, fot. P. Nowak - The Church of Crucifixion - a view from the side of the Chapel of Christ's Sepulchre, phot. P. Nowak

Tuż za kładką po lewej stronie drogi znajduje się niewielka kapliczka Cyreneusz. Wzniesiono ją na rzucie prostokąta i przykryto czterospadowym dachem. Na wszystkich czterech ścianach znajdują się arkady, zaopatrzone w żelazne kraty.

Kilkanaście metrów dalej zlokalizowana jest stacja Serce Matki Boskiej, wzniesiona na rzucie serca (Fig. 9).

Ściany kaplicy są gładkie, bez żadnych ozdób. Ponad nimi wznosi się spłaszczona kopuła, dostosowana kształtem do planu kaplicy.

Następnymi kaplicami na trasie są dwie małe, znacznie mniej efektowne i nieposiadające znaczącej wartości architektonicznej kaplice I Upadku i Włożenia Krzyża. Pierwsza z wymienionych jest bardzo podobna do kaplicy Cyreneusz, z kolei druga wzniesiona jest na planie krzyża łacińskiego, a na przecięciu się trójspadowych dachów posiada wieżyczkę na sygnaturkę.

Kilkanaście metrów dalej na skraju niewielkiego lasu wznosi się jedna z najpiękniejszych kaplic w Kalwarii Zebrzydowskiej, tj. Ratusz Piłata wraz z prowadzącymi do niego Świętymi Schodami „Gradusami” (Fig. 10).

Obiekty zbudowano na wzgórzu nazwanym Górą Moria. Do kaplicy prowadzi długi arkadowy przedsionek, wykonany niemal w całości z piaskowca (,Gradusy”). Jedynie same stopnie, prowadzące wprost do Ratusza Piłata, wykonane są $\mathrm{z}$ granitu. Jest to budowla na rzucie wydłużonego prostokąta, sklepiona kolebkowo. Wejścia zwieńczone są półkolistymi obeliskami po bokach, z kolei przy narożnikach znajdują się stożkowe przypory. Po bokach elewacji w górnej części „Gradusów” są kamienne balustrady. „Gradusy” powstały na wzór Świętych Schodów prowadzących do bazyliki św. Jana na Lateranie. Z kolei Ratusz Piłata wzniesiony został na planie krzyża greckiego. Cokół stanowią płyty wykonane z piaskowca, którym została nadana faktura groszkowana. Ściany wykonano w technologii muru zasypowego, na zewnątrz obłożono okładką ciosową. Przestrzeń środkową nakrywa kopuła wsparta na pendentywach. Z czterech krótkich ramion krzyża, zamkniętych prostokątnie, trzy nakryte są sklepieniem krzyżowym, czwarte, od zachodu sklepieniem beczkowym (Szablowski, 1933).

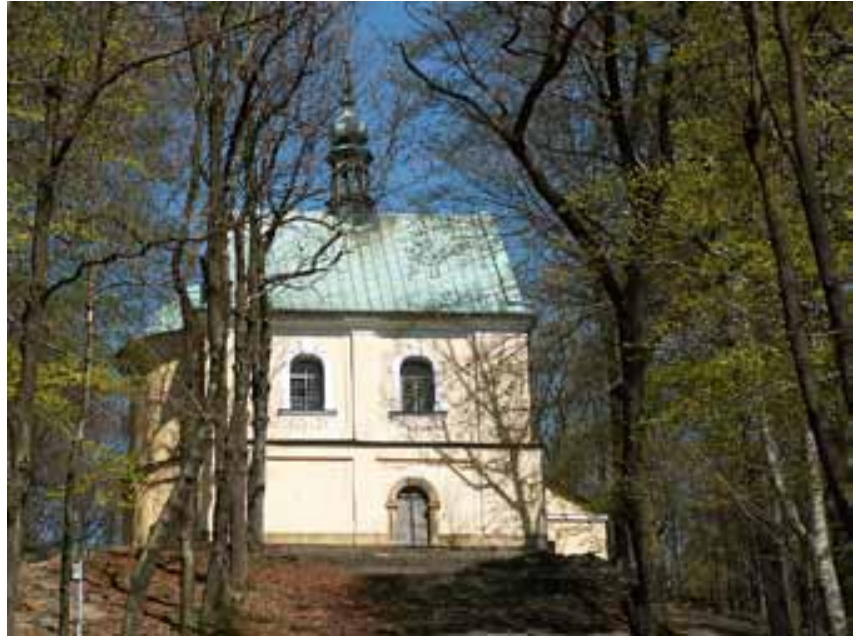

Fig.7 Kościół III Upadku, fot. P. Nowak • The Church of the Third Fall, phot. P. Nowak

Przy Ratuszu Piłata kończymy zwiedzanie Drogi Krzyżowej, warto natomiast pójść dalej deptakiem, aby zobaczyć również pozostałe obiekty należące już jednak do innych cykli dróżkowych.

\section{Skąd budulec, czyli o pochodzeniu materiału kamiennego użytego do budowy kaplic}

Obiekty sakralne w Kalwarii Zebrzydowskiej wykonane są w przeważającej mierze z kamienia, przy czym w czasie budowy stosowano najróżniejsze techniki. Część materiału budowlanego stanowią starannie obrobione bloki kamienne i płyty okładzinowe. Wiele ścian zostało wzniesionych w technologii muru zasypowego, pozwalającego na wykorzystanie także drobnego materiału skalnego oraz odpadów powstających w czasie obróbki bloków skalnych.

Ze względu na dogodne położenie i dobre parametry złożowe, głównym źródłem materiału kamiennego był, znajdu-

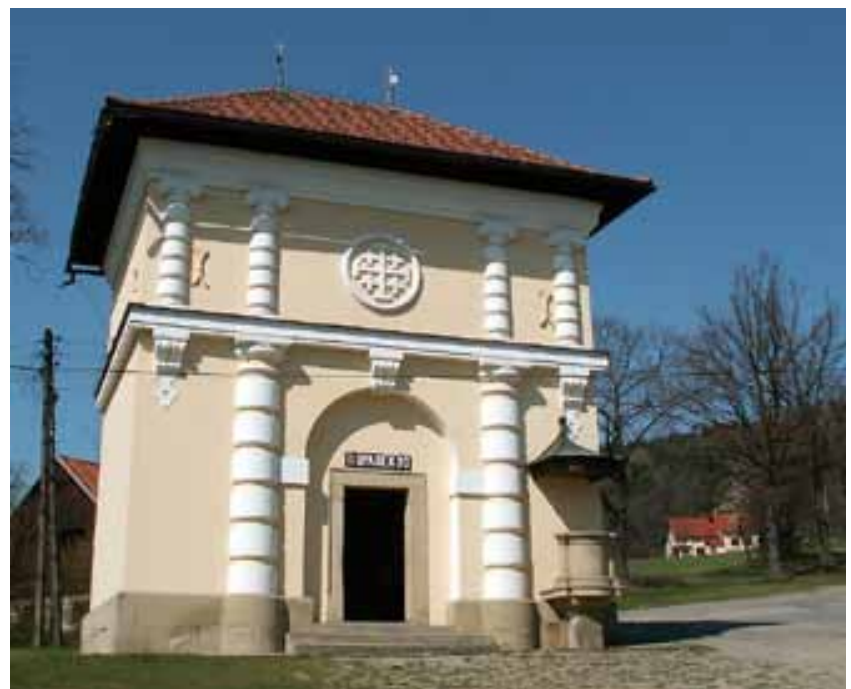

Fig. 8 Kaplica II Upadku tzw. Brama Zachodnia, fot. P. Nowak • The Chapel of the Second Fall: so-called Western Gate, phot. P. Nowak 


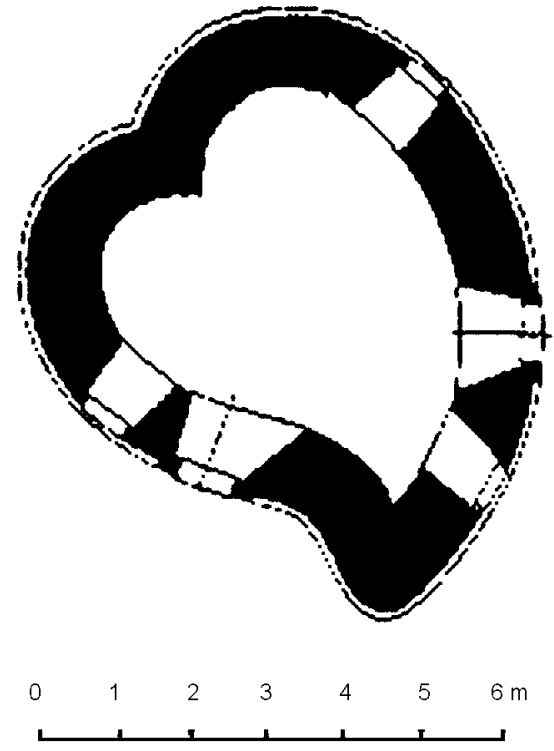

Fig. 9. Rzut poziomy kaplicy „Serce Matki Boskiej” ( Szablowski, 1933) • Horizontal projection of the „Heart of St. Mary” chapel

jący się na zboczach góry Żarek, kamieniołom piaskowców dolnolgockich o nazwie „Maria Magdalena” (Fig. 11).

Mimo, iż nie wygląda on zbyt okazale i obecnie zarósł już lasem, z szacunkowych danych wynika, że kamieniołom mógł bez problemu sprostać zapotrzebowaniu na surowiec do budowy kaplic. Pomiary obecnej wielkości wyrobiska wskazują, że wcina się ono w zbocze góry na tyle głęboko, iż wydobyta bryła złożowa mogła posiadać objętość rzędu $7200 \mathrm{~m}^{3}$. Oznacza to, iż urobku wystarczyłoby na wybudowanie około 100 obiektów o wielkości zbliżonej do kaplicy Grobu Chrystusa. Znacznie rzadziej spotyka się przykłady użycia innych skał jak np. wapień dębnicki, z którego wykonany jest klęcznik przed ołtarzem w Ratuszu Piłata czy granitowe schody w „Gradusach”.

Piaskowce dolnolgockie zastosowane w budowlach kalwaryjskich występują w dwóch odmianach barwnych. Jedna, jasnobeżowa, charakteryzuje się strukturą bezładną i niemal zawsze średnioziarnistą teksturą. Druga, ciemnobeżowa, jest znacznie bardziej zróżnicowana, gdyż poza różnymi odcieniami, od intensywnie żółtego, przez pomarańczowy, rdzawy po nawet czerwonawy, może posiadać zarówno strukturę bezład- ną, często zaburzoną rdzawymi smugami, jak i nieco rzadziej spotykaną, laminowaną. Ponadto może wykazywać zróżnicowanie pod względem uziarnienia, gdyż znacznie częściej spotyka się w niej ziarna frakcji grubej, choć fakcja średnia nadal dominuje. Przydatność piaskowców z wyrobiska „Maria Magdalena" do celów budowlanych wynika z ich wykształconia w postaci grubych ławic o miąższościach dochodzących do $180 \mathrm{~cm}, \mathrm{z}$ reguły niezbyt spękanych. Stwarzało to możliwości pozyskania dość dużych bloków kamienia i wykonania z nich w całości takich elementów jak kolumny czy ambonki. Piaskowce nie posiadają dużej zwięzłości, co jest ich walorem ale także niestety wadą. Są łatwe w obróbce, lecz równocześnie dość podatne na niszczące oddziaływanie różnego rodzaju czynników, co manifestuje się nie najlepszym stanem zachowania kamienia użytego do budowy kaplic. Niezbyt korzystne własności fizyczno-mechaniczne piaskowców (zwłaszcza nasiąkliwość wagowa wynosząca średnio 7,5\%) wynikają ze składu mineralnego szkieletu ziarnowego, ilości i rodzaju spoiwa (głównie ilastego) oraz ich tekstury i struktury. Należy jednak stwierdzić, że pomimo tych zastrzeżeń piaskowce dolnolgockie są bardzo atrakcyjnym materiałem budowlanym i mogłyby stanowić alternatywę dla innych piaskowców karpackich, zwłaszcza istebniańskich, powszechnie stosowanych w budownictwie.

\section{W drogę...}

Kalwaria Zebrzydowska ze względu na przedstawione walory turystyczne oraz bliskość położenia w stosunku do Krakowa i Wadowic bez wątpienia w najbliższych latach nadal będzie skupiać zainteresowanie turystów i pielgrzymów. Nasiliło się ono zaraz po śmierci papieża Jana Pawła II, gdy tysiące rodaków zapragnęło poznać miejsca, które były niezwykle bliskie sercu Karola Wojtyły. Jednak Kalwaria Zebrzydowska jest „,miejscem zadumy” nie tylko dla pielgrzymów, lecz także krajoznawców zakochanych w wędrówkach po beskidzkich szlakach. Stanowi także nie lada gratkę dla ludzi interesujących się architekturą oraz historią sztuki. Wśród nich bez wątpienia nie powinno zabraknąć także geologów, których dodatkowo mogą zainteresować przykłady zastosowania piaskowców dolnolgockich w budownictwie oraz historyczne miejsce ich eksploatacji. Nie pozostaje więc nic innego jak spakować plecak i zobaczyć to wszystko na własne oczy...

\section{Summary \\ The stone structures of the Way of the Cross in Kalwaria Zebrzydowska}

\section{Przemysław Nowak, Marek Rembiś}

Kalwaria Zebrzydowska is one of the most important Christian sanctuaries in Poland. This sacral complex, situated in a picturesque landscape and consisting of the monastery and 44 small churches and chapels of various types spreaded along almost 8-km-long route (Fig. 1.), is unique in the European scale. The wealth of architectonic forms (mainly Baroque) combined with a fascinating scenery of the area in which these are localized, and also with a more than 400-years-long history of the religious cult, is also unique. As a result, on the 1st December, 1999, the historic site of the Kalwaria praying paths was included into the UNESCO List of the World Heritage Sites as a sole object of this type world-wide. The chapels are an exceptional example of applying the Lower Lgota sandstones as construction stones, and they also give us the chance to get acquainted with the old art of masonry, according to which the stone material was utilized. These two possibilities should be stressed to appreciate geotouristic values of the site.

The history of foundation, followed by the construction of the monastery and first chapels in Kalwaria Zebrzydowska is inseparably associated with the history of the Zebrzydowski aristocratic family. The best known of them was, without any 
doubts, Mikołaj (Nicolaus), who conceived the whole idea around the year 1600. Being a very pious man, he decided to leave for the posteriority a clear mark of his faith in the form of a "Polish Jerusalem", i.e., a group of chapels imitating the original Way of the Cross (Wyczawski, 2006). He entrusted a Flemish architect Paul Baudarth, the designer of most of the chapels, also with the care of construction works. However, Mikołaj Zebrzydowski was not able to complete his great undertaking, since at a time he run short of money. After regaining "financial liquidity" and restarting the construction works, a sudden death stopped his endeavours on 17th May, 1620. However, due to him, besides the monastery-church complex there were 17 chapels already built, out of which five have become parts of the Way of the Cross (Wyczawski, 2006). After the death of Mikołaj, the care of Kalwaria and continuation of its extension were taken over by his son, Jan (John). As he was, like Mikołaj, a very pious man, he began the construction of new chapels as soon as three years after the death of his father. At the instance of him the next eight edifices were completed, including four belonging to the Way of the Cross, whereas two existing were extended (Wyczawski, 2006). His son Michał (Michael), the last member of the Zebrzydowski family, should be remembered from further extending the monastery complex in Kalwaria and buidling the Chapel of Our Lady of Miracles.

Being in Kalwaria Zebrzydowska, it is not a problem to visit the sacral objects, as the monastery, built on a mountain slope, is well visible from almost any point within the town (Fig. .2). When approaching the monastery one can see that a substantial part of the sacral complex has been set within the forest landscape. It is worthy explaining here that most of the religious sites have been arranged along one of two topical paths: the Paths of Jesus and the Paths of Mary, which go mostly parallel to each other but in opposite directions. Other sites, to mention only "The Hermitage of St. Helen", are additions and do not belong to any of these two major routes.

Approximately halfway from the monastery to the top of the Żarek Hill there is a small flattening, on which three structures have been built: the Church of Crucifixion, the "Christ's Sepulchre" and the Chapel of Anointing. At the same time, it is an excellent starting point for further, sacral and geological peregrination. And there are several options to move on from here. The most obvious seems to be the southwestern direction, towards the remaining chapels of the Way of the Cross. On the other hand, when choosing west, we will eventually reach the Bugaj village (Fig. 3), well-known for geologists as the occurrence of the so-called Bugaj granite, one of the Carpathian exotics. The granite is an olistholite situated within the Verovice shales. It is most probably just the rock used in constructing the stairs leading along the "Gradusy" (Saint Stairs), one of the stations of the Way of the Cross - the "Pilate's Residence".

Not reaching Bugaj, after passing by the westernmost chapel, i.e., the "Hermitage of Mary Magdalene", there is a le$\mathrm{ft}$-side branch of the main route that leads to the abandoned quarry named "Maria Magdalena" on the southern slope of Żarek Hill. There were once quarried the Lower Lgota sandstones applied to the construction of the most of sacral structures in Kalwaria Zebrzydowska. From the edge of the quarry wall a remarkable view opens to the southeast (Fig. 4). On the opposite, i.e., the northwestern slope of the Żarek Hill the-

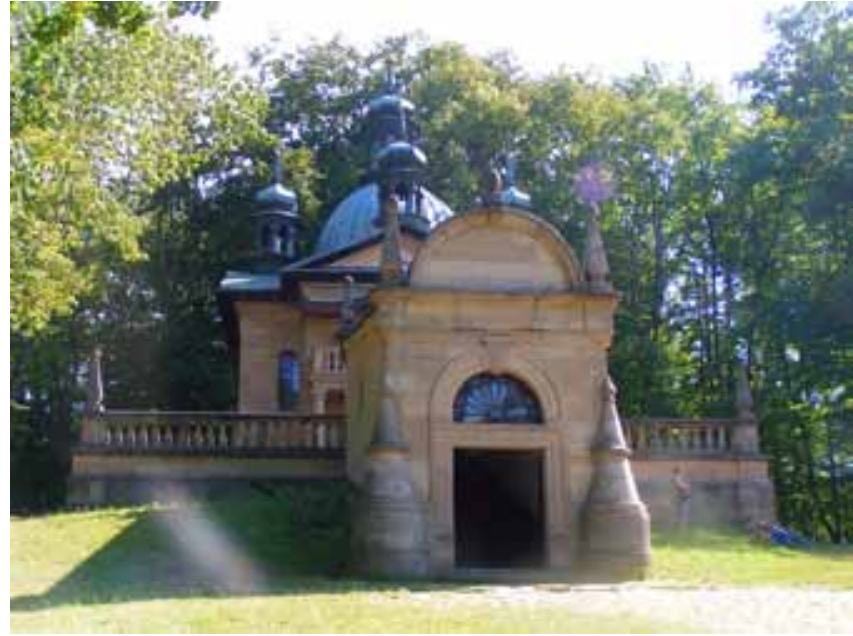

Fig. 10. Kaplica „Ratusz Piłata” z wyeksponowanym na pierwszym planie wejściem do Świętych Schodów - Gradusów, fot. G. Krupa - The „Pilate's Residence” chapel. The entrance to the Saint Stairs („Gradusy”) is exposed in the foreground, phot. G. Krupa

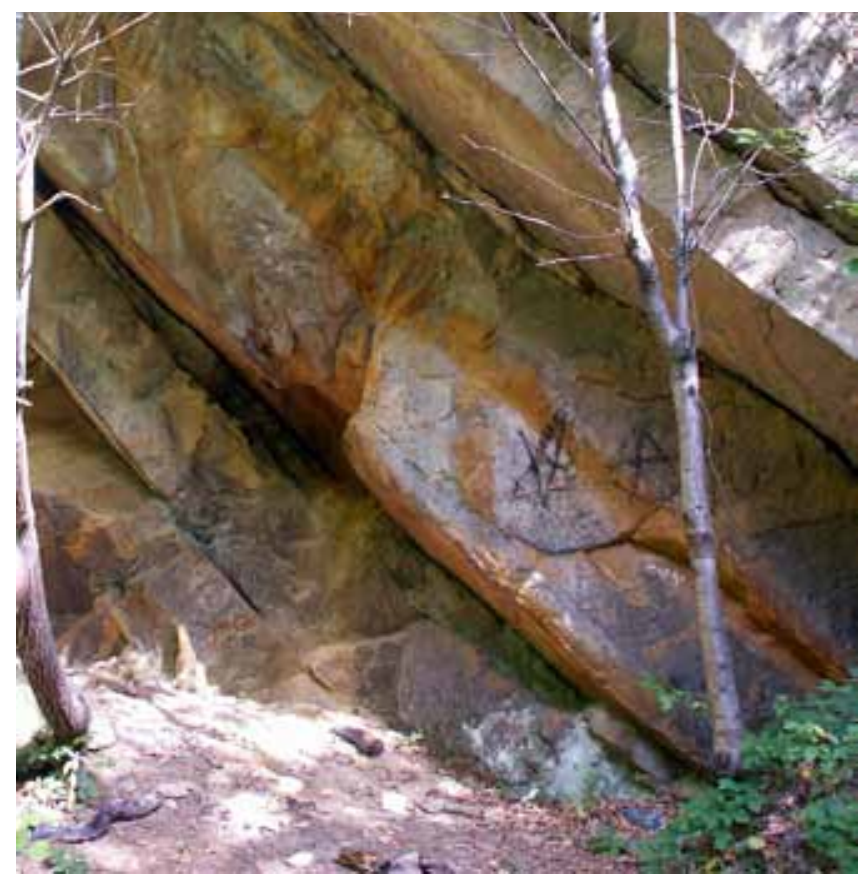

Fig. 11. Fragmenty wschodniej ściany wyrobiska piaskowców dolnolgockich „Maria Magdalena”, fot. P. Nowak • Fragments of the East wall of the Maria Magldalena quarry, phot. P. Nowak

re is a relatively large outcrop of the upper part of the Lgota Beds. Besides the two mentioned, attractive outcrops, being however only man-made sites, we can enjoy other, purely natural curiosities. The slopes of the Żarek Hill are covered with protected forest, and in a picturesque scenery of a dense, mixed wood and along its margins we can find rare, strictly protected plant species: periwinkle (Vinca minor), ivy (Hedera helix L.), carline (Carlina acaulis), terrestrial orchid (Gymnadenia conopea), lady's slipper (Cypripedium), horsetail (Equisetum maximum) and wild pepper - mezeron (Daphne mezercum) (Kowalik, 2004).

Into the list of more interesting sacral structures localized within the Way of the Cross we should include the Church of Crucifixtion and the "Christ's Sepulchre". The latter chapel (Fig. 5) 
has been erected entirely of ashlar sandstone and patterned after the original chapel of the Christ's Sepulchre in the Holy Land. In horizontal view it has rectangual outer contour closed from the west by five sides of dodecagon, whereas inside it splits into the two parts: the eastern, that is rectangular and the western, that is a square. An attractive lantern supported on Ionic columns surmounts the roof. Unfortunately, the chapel is considerably damaged, the sandstone of its façade is soiled by numerous dust layers and in places the rock peels off in larger fragments. Slightly up of the "Christ's Sepulchre" there is the Church of Crucifixion (Fig. 6), constructed partly of ashlar stone and partly of broken stone and bricks. The ground plan of the church is rectangular and its interior is divided into halves by two pillars and two semi-pillars, connected by arcades.

Going down to the southwest, visitors can see the remaining chapels. A building of a substantial size attracts our attention: it is the Church of the Third Fall (Fig.. 7), representing the ninth station of the Way of the Cross. Being a rectangle on a ground plan, it is closed from the front by a semi-circular apse and a square vestry. The façade and the elements of the ground course have been made of the broken sandstone and bricks, and architectonic details were carved also in sandstone.

Slightly farther there is the next structure of the Way of the Cross, the seventh station of a considerable size known as the Western Gate (or the Chapel of the Second Fall) (Fig. 8). It can be entered from opposite sides through two semicircular doors, i.e. from the east and the west. The façades of the chapel are divided by a sumptuous cornice, supported from the eastern side by two semi-pillars and three corbels.

A interesting object is laso the Chapel of St. Mary's Heart (Fig. 9) built on heart-like horizontal plan.

At the end of our excursion there is one of the most beautiful structures of the Kalwaria praying paths, i.e. the "Pilate's Residence". A long, arcaded porch ("Gradusy"), almost entirely made of sandstone, leads to the church (Fig. 10). Only the steps that eventually take us directly to the „Pilate's Residence" are made of granite. The "Gradusy" porch is patterned after the Saint Stairs leading to the St. John's Basilica on the Lateran in Rome. The porch has been erected on the plan of an elongated rectangle and covered with a barrel vault. The entrances are surmounted from both sides by semicircular obelisks, and the corners are strengthen by conical buttresses. The "Pilate's Residence", in fact a church, has been built on the plan of the Greek cross. Its ground course is lined with sandstone slabs. The walls constructed of ashlar stones are lined from the outside by ashlar slabs. The central part of the church is covered by a cupola resting on pendentives. Of the four short arms of the cross-shaped church with rectangular closing walls, three arms are covered by cross vaults, whereas the fourth - from the west - has a barrel vault. The central cupola is surmoun- ted by a lantern, whereas the four-side parts of the church are, in turn, covered by saddle roofs, closed with triangular pediments and embellished with ave-bells.

The sacral structures of Kalwaria Zebrzydowska have mostly been constructed using stone materials, following a whole range of construction techniques. Considering a convenient localization and favourable technical parameters of its sandstones, the "Maria Magdalena" quarry (Fig. 11) situated on the slopes of the Żarek Hill was the main source of the building material. The examples of applications of other stones, e.g. the Dębnik limestone or the Bugaj granite, are only occasional. Two colour varieties of the Lower Lgota sandstones used in the Kalwaria sacral buildings can be distinguished. The first is light-beige, with random structure and almost always mediumgrained texture. The other is dark-beige, with medium- and coarse-grained texture, and random (but sometimes also laminated) structure, often disturbed by rusty streaks. Probably, the sandstones would not have been so widely used if these were not developed in layers reaching a thickness of $180 \mathrm{~cm}$, which - as a rule - have no fractures and, therefore, could be quarried as large blocks. The strength of the sandstones is not high, which is both their valour and the fault - these can be easily worked out, but also rather prone to various damaging factors, which is reflected in rather poor preservation of the building stones of the chapels. The inferior physical and mechanical properties of the sandstones (particularly water absorbability, which mean value is $7.5 \%$ ) result from the mineral composition of the grain framework, the amount and type of cement (mainly clayey) as well as the rock texture and structure. It should be stated, however, that - despite those limitations - the Lower Lgota sandstones are a very attractive construction stone and could have been an alternative to other Carpathian sandstones, particularly to the Istebna sandstones, commonly used for building purposes.

Considering its tourist values and its proximity to Kraków and Wadowice, Kalwaria Zebrzydowska - without any doubts - should remain a centre of interest of tourists and pilgrims in the forthcoming years. The rising number of visitors was noticed immediately after the death of John Paul II, when thousands of his countrymen were seized with a desire to visit places that Karol Wojtyła had so deep in his heart. However, Kalwaria Zebrzydowska is a "magic site" not only for the pilgrims but also for devoted tourists wandering so numerous trails in the Beskidy Mts. Moreover, it is a place worthy visiting for people interested in architecture, in the history of art, and for geologists who, additionally, can study examples of the application of the Lower Lgota sandstones as construction stones and can examine the historic sites of their quarrying. So, we have nothing better to do than to pack our rucksacks, to go and to see everything described above with our own eyes ...

\section{Literatura:}

Kowalik T., 2004. Na Kalwarię Zebrzydowską, Gościniec, Kwartalnik PTTK, 2(15).

Szablowski J., 1933: Architektura Kalwarii Zebrzydowskiej (1600-1702). Rocznik Krakowski, 24: 1-118.
Wyczawski H.E., 2006: Kalwaria Zebrzydowska, Wyd. CALVARIANUM, Kalwaria Zebrzydowska: 1-113.

www.kalwaria.eu

www.kalwaria.ofm.pl/old/mapa.htm 